\title{
Pathology in skeletons of Peale's dolphin Lagenorhynchus australis from southern South America
}

\author{
Analía A. San Martín ${ }^{1,2, *}$, Silvina V. Macnie ${ }^{1}$, R. Natalie P. Goodall ${ }^{1,2, \mp}$, \\ Claudia C. Boy ${ }^{1,2}$
}

${ }^{1}$ Museo Acatushún de Aves y Mamíferos Marinos Australes (AMMA), Sarmiento 44, (9410), Ushuaia, Tierra del Fuego, Argentina ${ }^{2}$ Centro Austral de Investigaciones Científicas (CADIC) - CONICET, Bernardo Houssay 200, (9410), Ushuaia, Tierra del Fuego, Argentina

\begin{abstract}
Peale's dolphin Lagenorhynchus australis is frequently seen off the coast of southern South America, where it feeds among coastal kelp beds and occasionally strands. We searched for macroscopic evidence of skeletal lesions in 78 specimens of Peale's dolphin from 2 museum collections, which contain almost all of the species' skeletons known in collections worldwide. Thirtytwo specimens (41\%) had some type of osteological abnormalities. In 21 cases (66\%), congenital deformations were the most predominant abnormality found. Acquired lesions included (1) induced trauma: abnormal curvature ( $\mathrm{n}=5$ specimens) and fractures $(\mathrm{n}=2)$; $(2)$ infectious diseases: spondylo-osteomyelitis $(\mathrm{n}=3)$; and (3) degenerative diseases: exostoses $(\mathrm{n}=8)$ and spondylosis deformans $(\mathrm{n}=4)$. It is noteworthy that all of these animals died incidentally in gillnet entanglement and were presumably healthy at the time of death. The effect that different osseous lesions may have on an animal's quality of life may depend on the area of the spine affected and the number of vertebrae involved.
\end{abstract}

KEY WORDS: Cetacean $\cdot$ Stranding $\cdot$ Congenital anomalies $\cdot$ Tierra del Fuego

\section{INTRODUCTION}

Peale's dolphin Lagenorhynchus australis is the most commonly seen cetacean off the coast of Tierra del Fuego, where it feeds in coastal waters and occasionally strands. L. australis is mainly a coastal species common in the Southern Hemisphere from about $38^{\circ} \mathrm{S}$ in the SW South Atlantic and $33^{\circ} \mathrm{S}$ in the SE South Pacific, to south of Cape Horn (Goodall et al. 1997) and Namuncurá-Banco Burdwood Marine Protected Area (about $57^{\circ} \mathrm{S}$ ). This species seems to prefer the cold waters of the southern part of the continent.

Osseous lesions found in cetaceans commonly affect the vertebral body, the spinous processes, the transversal processes, zygapophyseal joints, and the ribs. To a lesser extent, lesions may be observed on the skull, scapula, sternum, and bones of the flippers (de Smet 1977, Pascual et al. 2000, Montes et al. 2004, Kompanje \& Van Leeuwen 2009, Arbelo et al. 2013). Osseous lesions of the vertebral column and associated structures can be produced by discarthrosis and zygarthrosis (spondylarthrosis or spondylosis deformans) (Peterson 1984, Kompanje 1995a,b, 1999, Kompanje \& Garcia Hartmann 2001, Galatius et al. 2009), infectious spondylo (discitis) (Kompanje 1995b, 1999, Sweeny et al. 2005, Félix et al. 2007), spondyloarthritis (spondyloarthropathy) (Kompanje 1999, Kompanje \& Garcia Hartmann 2001, Rothschild et al. 2005), and intraspongious disc herniation (Schmorl's nodes) (Kompanje \& Garcia Hartmann 2001). Spondylosis deformans occurs only in adult animals and is 
restricted to the vertebral body and adjacent processes. During the final stage of this disease, ankylosis occurs with destruction of the epiphysis (Kompanje 1995a). Spondylosis deformans occurs due to degeneration of the annulus fibrosus of the intervertebral disc, which leads to a secondary bone growth (Galatius et al. 2009).

Vertebral infections are mostly considered to be of 1 of 3 origins: hematogenous, direct local wound, or local infection produced by bacteria, viruses, fungi, or protozoa (Turnbull \& Cowan 1999) either by a direct penetration through a wound, blood stream infection, or infections in adjacent organs (Kompanje 1995b, 1999, Turnbull \& Cowan 1999). Post mortem examinations of these animals rarely occur within a few hours or days of stranding, when they are still fresh, making the diagnosis of cases of infectious spondylo (discitis) a difficult task (Kompanje 1999). Even more challenging is to identify the etiologic agent in cases limited to skeletal remains, given that most of the skeletal material in collections has been previously cleaned, which makes extraction of pathogen DNA difficult.

Congenital anomalies developed during ontogenesis are frequent and are similar to those found in humans and other mammals (Ortner \& Putschar 1985, Williams et al. 1989, Barnes 1994, Hall 2005). Exostoses have also been reported where bone growth occurs over the bone surface, especially where ligaments and tendons are inserted (de Smet 1977, Montes et al. 2004).

Bony lesions in cetaceans are well documented mainly for some Northern Hemisphere species (Kompanje 1995a,b, Galatius et al. 2009), but limited information is available about bony lesions in cetaceans of the Southern Hemisphere, including Peale's dolphin (Fragoso 2001, Ramos et al. 2001, Montes et al. 2004, Van Bressem et al. 2006, 2007, Laeta et al. 2010a,b, Fettuccia et al. 2013). The Museo Acatushún holds the world's largest collection of Peale's dolphin, and the aim of this work is to describe and quantify the osseous lesions found in this species.

\section{MATERIALS AND METHODS}

We examined 78 specimens of Peale's dolphin (Table 1), of which 18 were complete, with complete spines (Type A, sensu Goodall); 5 were incomplete, lacking some vertebrae (Type B); and 46 were groups of 3 to 60 vertebrae (Type E). Seventy of the examined specimens belong to the Goodall collection
(RNP) and are deposited in the Museo Acatushún de Aves y Mamíferos Australes (AMMA), located at Estancia Harberton, Tierra del Fuego, Argentina (Goodall 1978, Goodall et al. 1997). Specimens were collected from 1974 to present during beach surveys along the coast of northeastern Tierra del Fuego, from Cabo Espíritu Santo, $52^{\circ} 40^{\prime} \mathrm{S}$, to Cabo San Pablo, 542' ${ }^{\circ} \mathrm{S}$ (Goodall 1978, Goodall et al. 1994, 2008; Fig. 1). The remaining 8 skeletons were collected for scientific purposes in the Chilean channels between Isla Chiloé and Cape Horn by the K. S. Norris expedition in 1968 (K. S. Norris unpubl.) and are deposited in the Smithsonian Museum, Washington, DC, USA. Stranding date and location, condition and type of specimen, and when possible sex, age, and physical maturity are reported in Table 1.

For this work, only postcranial lesions were reviewed. The vertebrae and ribs of each specimen were examined macroscopically. The identification of the abnormalities was performed by observation of different patterns of osseous growth that are characteristic for different diseases in cetaceans. The skele-

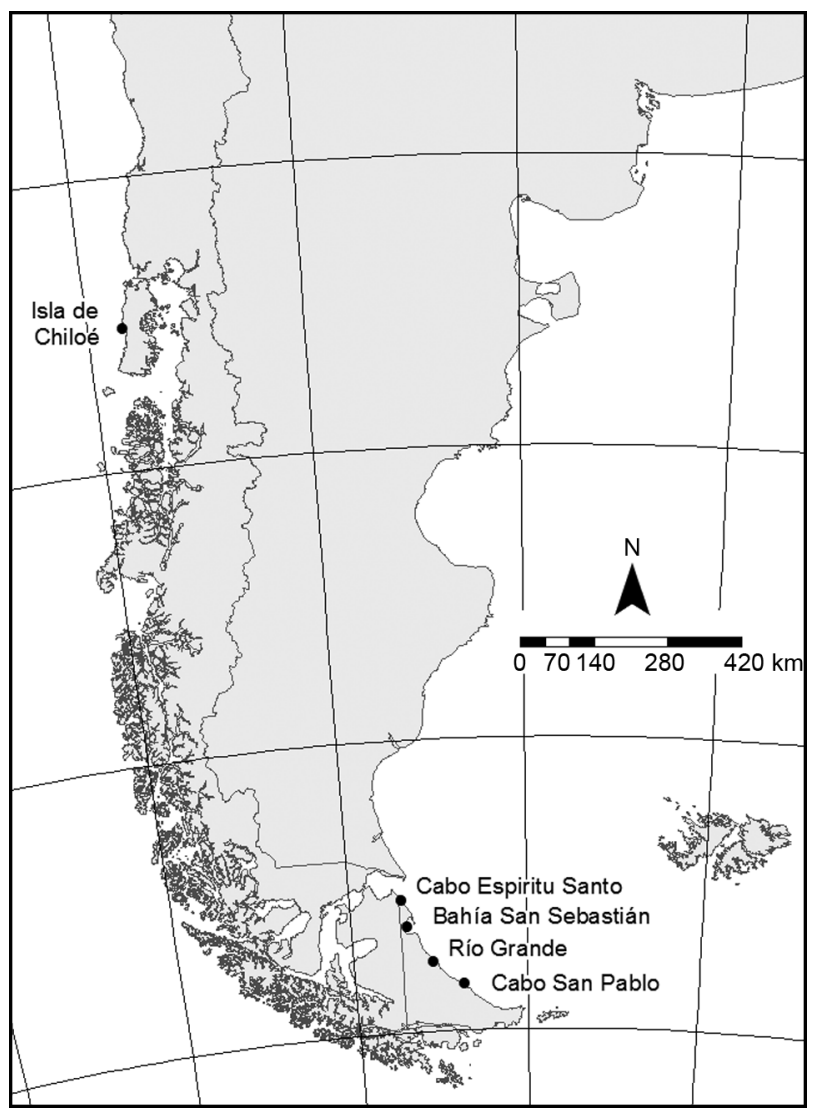

Fig. 1. Sites $(\bullet)$ where most of the investigated Lagenorhynchus australis stranded in Tierra del Fuego Island, Argentina, and Isla de Chiloé, Chile 
Table 1. Records of Lagenorhynchus australis specimens from southern South America, collected between 1974 and 2014 , examined in this study, with corresponding locality, sex, age (following Boy et al. 2011), the lesion found, and the region of the spinal column where the lesion was located. Specimen types were defined as follows: A: complete, with complete spines; B: incomplete, lacking some vertebrae; and E: groups of 3 to 60 vertebrae. -: not determined

\begin{tabular}{|c|c|c|c|c|c|c|}
\hline $\begin{array}{l}\text { Collection } \\
\text { no. }\end{array}$ & Sex & $\begin{array}{l}\text { Age } \\
(\mathrm{yr})\end{array}$ & $\begin{array}{l}\text { Specimen } \\
\text { type }\end{array}$ & Locality & Lesion(s) & Affected area(s) \\
\hline RNP0 97 & - & - & $\mathrm{E}$ & Península Páramo & Exostosis & Caudal \\
\hline RNP 179 & - & - & E & Estancia Moat & Congenital & Cervical \\
\hline RNP 269 & - & 1.9 & A & Bahía San Sebastián & Congenital & Cervical \\
\hline RNP 427 & - & - & E & Cabo Peñas & Congenital & Cervical \\
\hline RNP 554 & - & - & E & Río Cullen & Spondylosis deformans & Thoracic \\
\hline RNP 649 & $\mathrm{~F}$ & 4 & A & Península Páramo & Congenital & Cervical \\
\hline RNP 713 & - & - & $\mathrm{E}$ & Porvenir, Faro Pta. Palo (Chile) & Exostosis & Thoracic, Lumbar \\
\hline RNP 716 & $\mathrm{~F}$ & 3 & A & Bahía Slogget & $\begin{array}{l}\text { Congenital } \\
\text { Exostosis }\end{array}$ & $\begin{array}{l}\text { Cervical } \\
\text { Lumbar, Caudal }\end{array}$ \\
\hline RNP 717 & $\mathrm{~F}$ & 1.7 & A & Bahía Slogget & Congenital & Cervical \\
\hline RNP 718 & $\mathrm{~F}$ & 3 & A & Bahía Slogget & Congenital & Cervical \\
\hline RNP 719 & $\mathrm{~F}$ & 13 & A & Bahía Slogget & Congenital & Cervical \\
\hline RNP 720 & $\mathrm{~F}$ & 3.8 & A & Bahía Slogget & Congenital & Cervical \\
\hline RNP 753 & $\mathrm{~F}$ & 11 & A & Bahía San Sebastián & $\begin{array}{l}\text { Congenital } \\
\text { Exostosis }\end{array}$ & Cervical, Thoracic \\
\hline RNP 761 & - & 0.8 & A & Bahía San Sebastián & Congenital & Cervical \\
\hline RNP 777 & - & - & $\mathrm{E}$ & Estancia Sara, Puesto & Exostosis & Thoracic \\
\hline RNP 836 & - & 7 & A & Bahía San Sebastián & Congenital & Cervical \\
\hline RNP 889 & - & - & $\mathrm{E}$ & Río Grande, La Misión & Congenital & Cervical \\
\hline RNP 918 & - & - & $E$ & Bahía Valentín & Spondylosis deformans & Thoracic \\
\hline RNP 1149 & - & - & E & Estancia Sara, Puesto & $\begin{array}{c}\text { Exostosis } \\
\text { Spondylosis deformans }\end{array}$ & $\begin{array}{l}\text { Thoracic } \\
\text { Lumbar }\end{array}$ \\
\hline RNP 1164 & $\mathrm{~F}$ & 1.9 & A & Rio Lainez & Congenital & Cervical \\
\hline RNP 1184 & - & - & $\mathrm{E}$ & ES, Puesto & Congenital & Cervical \\
\hline RNP 1475 & $\mathrm{~F}$ & 7 & B & Cabo Espíritu Canto & Congenital & Cervical, Lumbar \\
\hline RNP 1476 & M & 2 & $\mathrm{~B}$ & Cabo Espíritu Canto & Congenital & Cervical, Lumbar \\
\hline RNP 1760 & M & 5 & A & Península Páramo & Infection & Lumbar \\
\hline RNP 1855 & - & 5 & $\mathrm{~A}$ & Península Páramo & Congenital & Cervical \\
\hline RNP 2024 & $\mathrm{~F}$ & 4 & A & Estancia Sara & Congenital & Cervical \\
\hline RNP 2577 & M & 0.8 & $\mathrm{~A}$ & Bahía San Sebastián & Congenital & Cervical \\
\hline RNP 2796 & - & - & A & Bahía San Sebastián & $\begin{array}{c}\text { Infection } \\
\text { Spondylosis deformans } \\
\text { Exostosis }\end{array}$ & $\begin{array}{l}\text { Cervical, Thoracic, Caudal } \\
\text { Thoracic } \\
\text { Caudal }\end{array}$ \\
\hline RNP 2805 & - & - & B & Punta Sinai & Exostosis & Lumbar \\
\hline USNM 395345 & $5 \mathrm{~F}$ & & & Isla Coloca, Chile & Congenital & Lumbar \\
\hline
\end{tabular}

ton of Peale's dolphin is typically composed of 66 vertebrae: 7 cervical (C), 13 thoracic (Th), 15 lumbar (L), and 31 caudal (Ca) (Brownell et al. 1999). After the abnormal skeletons had been identified, they were classified into types of specimens and types of lesions, and if possible, their probable causes were determined (Table 2).

\section{RESULTS}

Thirty-two of the 78 (41\%) specimens had osseous abnormalities on the vertebrae and ribs. The most frequent osseous lesion were congenital anomalies observed in 21 specimens $(66 \%$ of the specimens with abnormalities), and among these, the most fre-
Table 2. Skeletal lesions found in 32 of 78 examined Peale's dolphins Lagenorhynchus australis from southern South America, collected between 1974 and 2014. Several individuals presented more than 1 type of lesion. N: number of individuals; Ind. (\%): percentage of affected individuals

\begin{tabular}{|lcc|}
\hline Lesion & $\mathrm{N}$ & Ind. (\%) \\
\hline Spondylosis deformans & 4 & 13 \\
Congenital anomalies & 21 & 66 \\
Infection & 3 & 9 \\
Trauma induced & 5 & 16 \\
Periostitis & 8 & 25 \\
\hline
\end{tabular}

quent (14 specimens) occurred in cervical vertebrae C5, C6, and C7 (though most predominantly on C7), which presented cervical ribs (Fig. 2). 


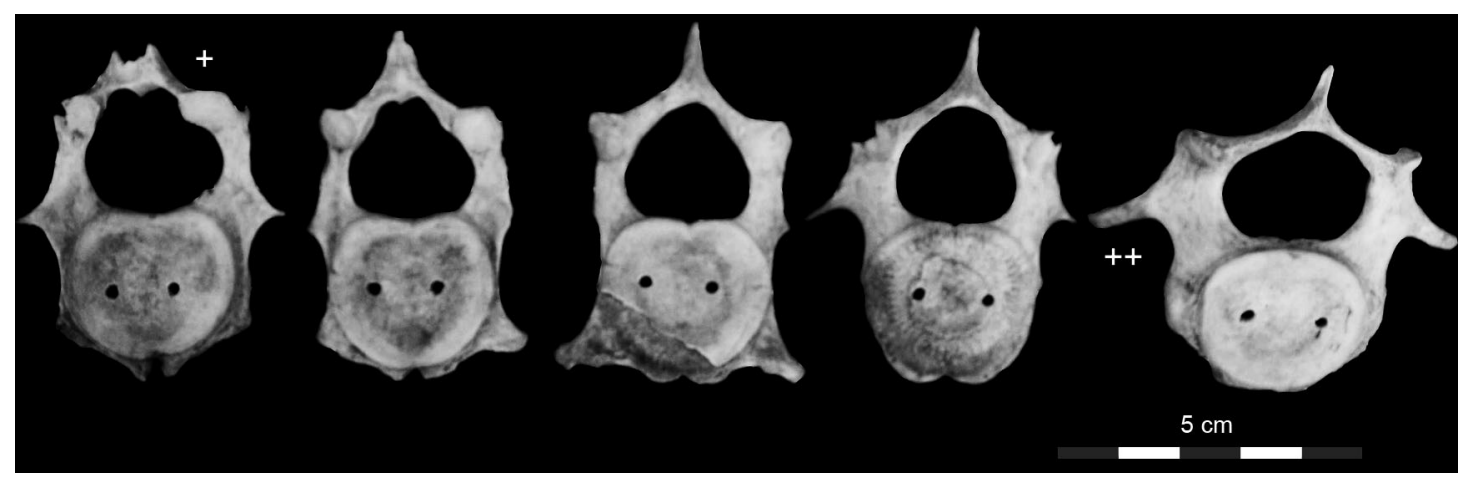

Fig. 2. Cervical vertebrae (C3 to C7) of Lagenorhynchus australis with congenital anomalies. Spine bifida occulta in vertebra C3 (+). In C7, the transverse processes are longer than normal (++)

Other congenital anomalies found in Lagenorhynchus australis were an unfused neural arch, fused neural spinous processes, and spina bifida occulta. The unfused neural arch was found in 4 dolphins; 3 of these affected the $\mathrm{C} 3$ and the $\mathrm{C} 7$ vertebrae. The spinous processes of 2 lumbar vertebrae were fused in 4 specimens; 2 of these were found together on the beach, with the same pattern: the upper part of the neural spines of lumbar vertebrae L10 and L11 were fused together (Fig. 3). The specimens also had fused spinous processes of 2 adjacent lumbar vertebrae, but it was not possible to determine their location because the vertebrae of the lumbar region were not complete. In all cases, the fusion was smooth, showing none of the typical signs of osteomyelitis or any other condition that may have caused the fusion.

The acquired or trauma-induced lesions observed were fractures or abnormal curvatures, such as the curving of spiny or transverse processes of the vertebrae modifying the column axis. We observed $5(16 \%)$ specimens with abnormal curvature of the spinous processes of the thoracic vertebrae, and in all cases, this curvature involved groups of 2 to 6 vertebrae.

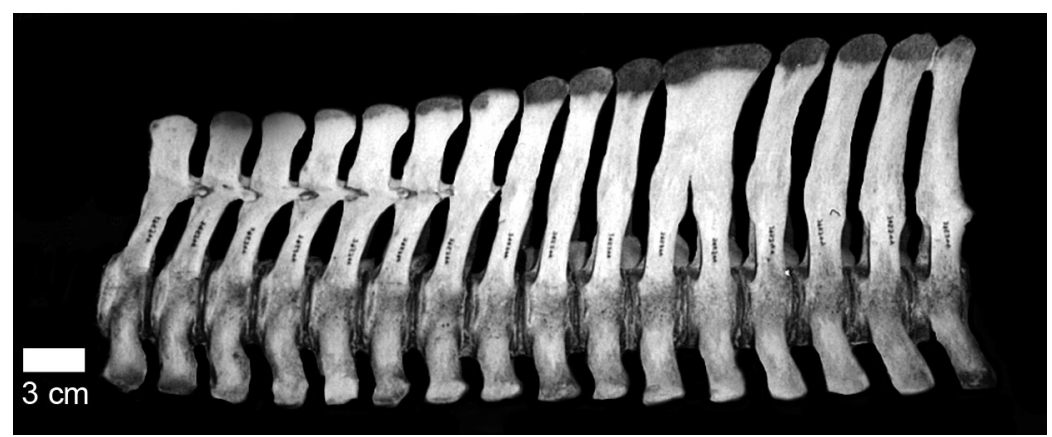

Fig. 3. Abnormal congenital fusion of the spinous processes of Lagenorhynchus australis. This anomaly is repeated in 4 specimens; all fusions occurred in the lumbar region but varied in their position in the vertebra. Left: caudal end; right: cranial end
Regarding lesions related to infections, 3 specimens $(9 \%)$ had lesions compatible with spondylo-osteomyelitis (Fig. 4). In 2 of these, the infections were located on only 2 adjacent vertebrae. In the third specimen, the degree of infection was severe; the cervical vertebrae exhibited ventral marginal osteophytes with growth, and on the articular surface of the atlas, we observed marked erosion and fistula formation. Several pairs of thoracic vertebrae were fused through the formation of excessive and disorganized ankylosis, and a fistula caused by the drainage of pus was visible. Vertebrae Th2 and Th3 were fused by ankylosis, Th3 had severely eroded epiphysis, Th4 and Th5 were fused by the formation of exuberant marginal osteophytes, Th6 showed erosion of the epiphysis and formation of marginal ventral osteophytes, Th7 showed marginal osteophytes, and Th8 showed the formation of ventral marginal osteophytes with insertion in Th7.

Eight specimens $(25 \%)$ were found with lesions caused by exostoses in the spinous and transverse processes of thoracic, lumbar, and caudal vertebrae. In 3 of them, exostosis was found in the transverse processes of 2 thoracic vertebrae and in the spinous processes of Th1 to Th8. Exostoses were observed in the transverse processes of lumbar vertebrae of 4 animals, and finally in the transverse processes of the caudal vertebrae of 1 animal.

Four specimens (13\%) showed evidence of spondylosis deformans. This degenerative disease was found in varying degrees of severity. Two of the specimens showed the first degree of severity, i.e. erosion of the epiphysis and marginal osteophytes. The other 2 animals had the most advanced signs of 


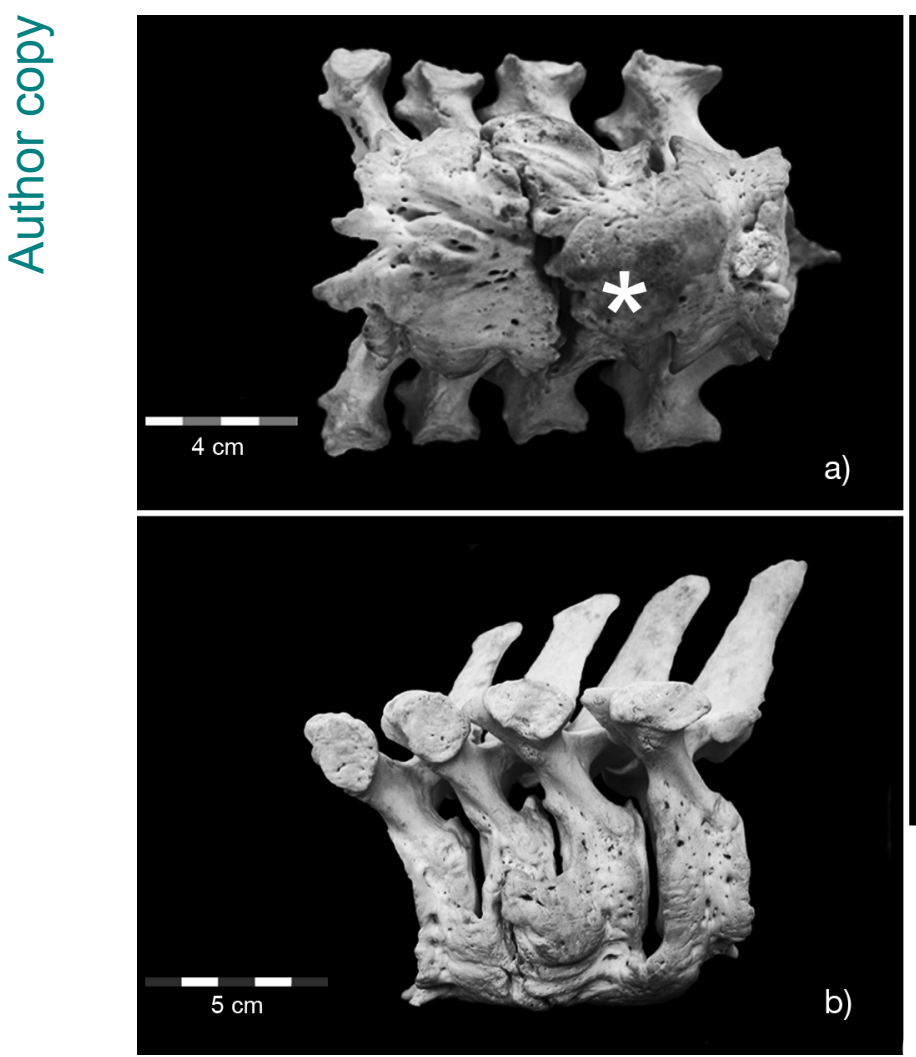

the disease. One of them presented the 'parrot beak' (sensu Kompanje 1996) and advanced osteophytes growing in the thoracic vertebra Th4. The other specimen showed only 3 vertebrae fused together by formation of smooth ankylosis, representing the final stage of the disease.

\section{DISCUSSION}

The Lagenorhynchus australis specimens analyzed here represent almost all of the skeletons available in worldwide collections, and we found that $41 \%$ of the specimens had diseases reported for other species such as bottlenosed dolphins Tursiops truncatus, white-beaked dolphins L. albirostris, and Commerson's dolphins Cephalorhynchus commersonii commersonii, among others. Skeletal abnormalities are well documented in many species of cetaceans from around the world, including both dolphins and whales (e.g. de Smet 1977, Peterson 1984, Alexander et al. 1989, Kompanje 1999, Fragoso 2001, Montes et al. 2004, Van Bressem et al. 2006, 2007, Félix et al. 2007, Laeta et al. 2010a,b). The great majority of the research on cetacean skeletal abnormalities has been conducted on species from the Northern Hemisphere (Peterson 1984, Kinze 1986, Alexander et al. 1989,

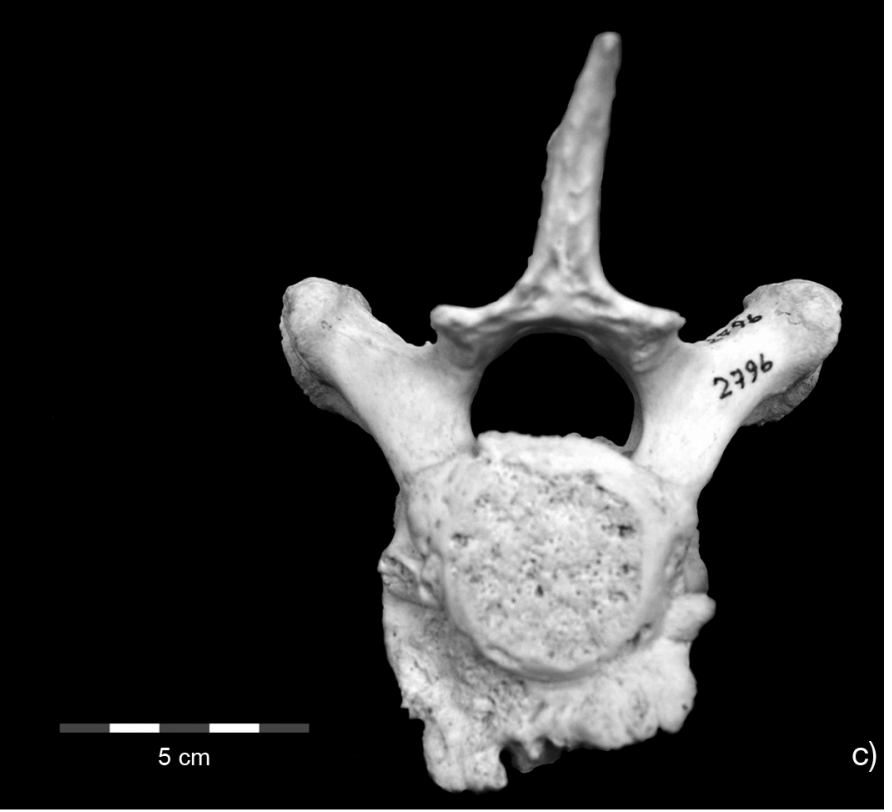

Fig. 4. Thoracic vertebra of Lagenorhynchus australis with infections, showing (a) ventral view of exuberant and disorganized osseous growth and the formation of ankylosis ( $\star$ : osteophyte), (b) lateral view, where ventral fusion of the vertebra is seen by the formation of the osteophytes, and (c) destruction of the intervertebral disc and growth of osteophytes

Kompanje 1996, 1999, Van Bressem et al. 2006, Félix et al. 2007, Galatius et al. 2009, Fettuccia et al. 2013) and some on species of northern South America (Ramos et al. 2001, Montes et al. 2004, Van Bressem et al. 2007, Laeta et al. 2010a,b).

The most frequent lesions in L. australis were congenital anomalies, which were found in $66 \%$ of the specimens with bone pathologies, and with a higher frequency than those found in the other common dolphin in Tierra del Fuego, viz. Commerson's dolphin (San Martín 2014). The most frequent congenital anomalies in cetaceans are the unfused neural arch and cervical rib, e.g. in Guiana dolphins Sotalia guianensis (Laeta et al. 2010b) and C. commersonii commersonii (San Martín 2014). In C. commersonii, the cervical rib was only found in C7. In L. australis, the cervical rib was found in $\mathrm{C} 6$ and $\mathrm{C} 7$ : the most frequent lesions found were the presence of cervical ribs $(67 \%)$, followed by an unfused neural arch $(19 \%)$. The proportion of individuals with unfused neural arches, as well as the number of vertebrae per individual involved, was lower in L. australis than in other species. For example, San Martín (2014) found unfused neural arches in C. commersonii commersonii, not only in C6 and C7, but also in C3, Th1, and Th2. Both congenital anomalies are mainly related to nutritional deficiencies in the B9 vitamin complex 
(Minns 1996, Fleming \& Copp 1998, Jablonski \& Chaplin 2000), and in the case of the marine environment, these nutritional deficiencies may be related to environmental changes (Jablonski \& Chaplin 2000). The observation of older individuals with congenital abnormalities suggests that this kind of anomaly does not affect the survival of individuals.

Exostoses were the second most common lesion found in the Peale's dolphin skeletons. The few reports that have described this disease in cetaceans referred to cases of exostosis is in the skull (de Smet 1977), in the vertebral body (Nathan 1962, Kompanje 1999), at the joint of the humerus and scapula, and in the ribs (Groch et al. 2012).

The remaining lesions present in Peale's dolphin were found in low numbers, affecting only a few specimens. Spondylosis deformans and joint osteoarthritis are lesions related to aging and wear of the joints. Spondylosis deformans is a disease well documented in other species of cetaceans such as L. albirostris, S. guianensis, Atlantic spotted dolphin Stenella frontalis, humpback whales Megaptera novaeangliae, and beluga (or white) whales Delphinapterus leucas, among others (Kompanje 1995a, 1996, 1999, Furtado \& Simões-Lopes 1999, Galatius et al. 2009, Groch et al. 2012). Spondylosis deformans causes the loss of flexibility due to the formation of large osteophytes that immediately cause rigidity of the vertebral bodies. Although in L. australis this disease was observed only in the initial stages (first degree of severity), the consequence, depending on the area of the vertebral column that is affected, is decreased mobility of the individual.

Two individuals presented osteomyelitis. One of these cases was a point infection that affected only 2 vertebrae, and the other specimen showed a more severe infection that affected several thoracic vertebrae. In both cases, it was not possible to determine the cause, given that we had only skeletons and lacked samples of soft tissues for examination of pathogens. Depending on the degree of infection and the affected regions, osteomyelitis would lead to death of the individual. Post mortem examination of animals stranded in Tierra del Fuego can rarely be performed within a few hours or days after the stranding occurs. Furthermore, and depending on the condition of the carcass (e.g. freshly dead, moderately decomposed), it can be difficult to collect the samples required for the proper diagnosis of various infectious diseases (Kompanje 1999). Most strandings that occur on the coast of Tierra del Fuego are the result of bycatch in gillnets, suggesting that in our specimens, death was not caused by infections.
Acknowledgements. We are grateful to the Committee for Research and Exploration of the National Geographic Society for grants which have funded our field research. We thank Total Austral SA of Argentina and the Fondation Total D'Entreprise of France for granting fellowships to S.V.M. to study cetacean pathology. We also thank the many volunteers who contributed to the collection and cleaning of specimens over the years. Estancias Harberton, Moat, Viamonte, San Martín, and Cullen assisted the Goodall team during the expeditions. J. G. Mead kindly provided access to the specimens under his care at USNM. We would also like to thank E. J. O. Kompanje for providing valuable literature, for sharing his expertise on cetacean pathology, and for reviewing and improving this manuscript. Thanks also E. Gimeno, M. Van Bressem, and A. C. M. Schiavini for reviewing drafts and offering valuable advice. Finally, we thank Florencia Sangermano and Romina Pousa for the revision of the language.

\section{LITERATURE CITED}

Alexander JW, Mobashir AS, Riegel LS (1989) Vertebral osteomyelitis and suspected diskospondylitis in an Atlantic bottlenose dolphin (Tursiops truncatus). J Wildl Dis 25:118-121

Arbelo M, Espinosa de Los Monteros A, Herráez P, Andrada $M$ and others (2013) Pathology and causes of death of stranded cetaceans in the Canary Islands (1999-2005). Dis Aquat Org 103:87-99

Barnes E (1994) Developmental defects of the axial skeleton in paleopathology. University Press of Colorado, Niwot, $\mathrm{CO}$

Boy CC, Dellabianca N, Goodall RNP, Schiavini ACM (2011) Age and growth in Peale's dolphin (Lagenorhynchus australis) in subantarctic waters off southern South America. Mamm Biol 76:634-639

Brownell RL Jr, Crespo EA, Donahue MA (1999) Peale's dolphin Lagenorhynchus australis (Peale, 1848). In: Ridgway $\mathrm{SH}$, Harrison R (eds) Handbook of marine mammals, Vol 6. The second book of dolphins and the porpoises. Academic Press, San Diego, CA, p 105-120

de Smet WMA (1977) The fate of old bottlenosed dolphins, Tursiops truncatus, in nature, as revealed by the condition of their skeletons. Aquat Mamm 5:78-88

Félix F, Haase B, Aguirre WE (2007) Spondylitis in a humpback whale (Megaptera novaeangliae) from the southeast Pacific. Dis Aquat Org 75:259-264

Fettuccia DC, Da Silva VMS, Simões-Lopes PC (2013) Osteological alterations in the tucuxi Sotalia fluviatilis (Cetacea, Delphinidae). Iheringia Sér Zool 103:255-259

Fleming A, Copp AJ (1998) Embryonic folate metabolism and mouse neural tube defects. Science 280:2107-2109

Fragoso ABL (2001) Alterações morfológicas e patológicas em esqueletos de boto-cinza Sotalia fluviatilis (Gervais, 1853) do litoral do estado do Rio de Janeiro. MSc thesis, Universidade Federal do Rio de Janeiro/Museu Nacional, Rio de Janeiro

Furtado MHBC, Simões-Lopes PC (1999) Alterações senildegenetarivas e variações anatômicas na coluna vertebral de pequenos cetáceos. Biotemas 12:133-147

Galatius A, Sonne C, Kinze CC, Dietz R, Jensen JEB (2009) Occurrence of vertebral osteophytosis in a museum sample of white-beaked dolphins (Lagenorhynchus albirostris) from Danish waters. J Wildl Dis 45:19-28 
Goodall RNP (1978) Report on the small cetaceans stranded on the coasts of Tierra del Fuego. Rep Int Whaling Comm 30:197-230

Goodall RNP, Schiavini ACM, Fermani R (1994) Net fisheries and net mortality of small cetaceans off Tierra del Fuego, Argentina. Rep Int Whal Comm Spec Issue 15: 295-304

Goodall RNP, de Haro JC, Fraga F, Iguiñez MA, Norris KS (1997) Sightings and behavior of Peale's dolphins, Lagenorhynchus australis, with notes and dusky dolphins, L. obscurus of southernmost South America. Rep Int Whaling Comm 47:757-775

Goodall RNP, Dellabianca N, Boy CC, Benegas LG, Pimper LE, Riccialdelli L (2008) Review of small cetaceans stranded or incidentally captured on the coasts of Tierra del Fuego, Argentina, over 33 years. Sci Comm Doc SC/60/SM21. International Whaling Commission, Cambridge

Groch KR, Marcondes MCC, Colosio AC, Catão-Dias JL (2012) Skeletal abnormalities in humpback whales Megaptera novaeangliae stranded in the Brazilian breeding ground. Dis Aquat Org 101:145-158

Hall BK (2005) Bones and cartilage. Developmental and evolutionary skeletal biology. Elsevier Academic Press, San Diego, CA

Jablonski NG, Chaplin G (2000) The evolution of human skin coloration. J Hum Evol 39:57-106

Kinze CC (1986) Note on the occurrence of spondylitis deformans in a sample of harbor porpoises (Phocoena phocoena) taken in Danish waters. Aquat Mamm 12:25-27

Kompanje EJO (1995a) On the occurrence of spondylosis deformans in white-beaked dolphins Lagenorhynchus albirostris (Gray, 1846) stranded on the Dutch coast. Zool Meded (Leiden) 69:231-250

Kompanje EJO (1995b) Differences between spondyloosteomyelitis and spondylosis deformans in small odontocetes based on museum material. Aquat Mamm 21: 199-203

Kompanje EJO (1996) Intervertebral disc degeneration and discarthrosis in white-beaked dolphins (Lagenorhynchus albirostris). European Association of Zoo- and Wildlife Veterinarians (EAZWV), Rostock, p 21-25

Kompanje EJO (1999) Considerations on the comparative pathology of the vertebrae in Mysticeti and Odontoceti; evidence for the occurrence of discarthrosis, zygarthrosis, infectious spondylitis and spondyloarthritis. Zool Meded (Leiden) 73:99-130

Kompanje EJO, Garcia Hartmann M (2001) Intraspongious disc herniation (Schmorl's node) in Phocoena phocoena and Lagenorhynchus albirostris (Mammalia: Cetacea, Odontoceti). Deinsea 8:135-141

Kompanje EJO, Van Leeuwen MCJ (2009) Skulls of the harbour porpoise Phocoena phocoena (Mammalia: Cetacea, Odonticeti) from Mauritania and Morocco, West Africa. Deinsea 13:41-53

Laeta M, Souza SMF, Siciliano S (2010a) Anomalías ósseas

Editorial responsibility: Sven Klimpel,

Frankfurt, Germany congênitas em Sotalia guianensis (Mammalia, Cetacea, Delphinidae) da costa centro-norte do estado do Rio de Janeiro. Pesqui Vet Bras 30:484-490

Laeta M, Souza SMF, Siciliano S (2010b) Cervical ribs and cleft arches in Brazilian Sotalia guianensis: contribution to comparative studies of skeletal morphology in northern and southeastern specimens. Latin Am J Aquat Mamm 8:151-165

Minns RA (1996) Folic acid and neural tube defects. Spinal Cord 34:460-465

Montes DI, Chavera AC, Van Bressem MF, Perales RC, Falcón NP, Van Waerebeek K (2004) Descripción y evaluación anatómica de lesiones óseas cráneo-mandibulares en cetáceos odontocetos del mar peruano. Rev Invest Vet Perú 15:13-24

Nathan H (1962) Osteophytes of the vertebral column: an anatomical study of their development according to age, race and sex with consideration of their aetiology and significance. J Bone Joint Surg 44-A:243-268

Ortner DJ, Putschar WGJ (1985) Identification of pathological conditions in human skeletal remains. Smithsonian Institution Press, Washington, DC

Pascual S, Abollo E, López A (2000) Elemental analysis of cetacean skull lesions associated with nematode infections. Dis Aquat Org 42:71-75

Peterson RA (1984) Spondylitis deformans in a Bryde's whale (Balaenoptera edeni Anderson) stranded on the southern coast of Queensland. J Wildl Dis 20:250-252

Ramos RMA, Di Beneditto APM, Souza SM (2001) Bone lesions in Sotalia fluviatilis (Cetacea) as a consequence of entanglement: case report. Braz J Vet Res Anim Sci 38: 192-195

Rothschild BM, Mitchell ED, Moore MJ, Early GA (2005) What causes lesions in sperm whale bones? Science 308: 631-632

San Martín AA (2014) Descripción y cuantificación de las lesiones oseas presentes en la tonina overa Cephalorhynchus commersonii commersonii (Lacépéde, 1804). Degree thesis, Universidad Nacional de Mar del Plata

Sweeny MM, Price MJ, Jones GS, French TW, Early GA, Moore MJ (2005) Spondylitic changes in long-finned pilot whales (Globicephala melas) stranded on Cape Cod, Massachusetts, USA, between 1982 and 2000. J Wildl Dis 41:717-727

> Turnbull BS, Cowan DF (1999) Synovial joint disease in wild cetaceans. J Wildl Dis 35:511-518

- Van Bressem MF, Van Waerebeek K, Montes D, Kennedy S and others (2006) Diseases, lesions and malformations in the long-beaked common dolphin Delphinus capensis from the Southeast Pacific. Dis Aquat Org 68:149-165

Van Bressem MF, Reyes JC, Félix F, Echegaray M and others (2007) A preliminary overview of skin and skeletal diseases and traumata in small cetaceans from South American waters. Lat Am J Aquat Mamm 6:7-42

Williams PL, Warwick R, Dyson M, Banniester LH (1989) Gray's anatomy. Churchill Livingstone, Oxford

Submitted: September 7, 2015; Accepted: April 29, 2016

Proofs received from author(s): May 19, 2016 